\title{
The Impact of Broadband Networks on Growth and Development in South America
}

\author{
Zoltán Bánhidi^ \\ 1 Department of Economics, Faculty of Economic and Social Sciences, Budapest University of Technology and Economics, \\ H-1521 Budapest, P. O. B. 91, Hungary \\ * Corresponding author, e-mail: banhidiz@kgt.bme.hu
}

Received: 28 August 2019, Accepted: 25 April 2020, Published online: 09 September 2020

\begin{abstract}
Broadband networks can play a special role as "general purpose technologies" that enable or facilitate the use of other Information and Communication Technologies (ICTs), including a plethora of internet-based services, such as e-commerce, e-government, e-learning or social media. Due to the better quality and availability of statistical data, most empirical studies on the economic effects of broadband have focused on their impact on growth, employment and productivity in developed countries. In this study, we set out the reasons why these economic effects should also be relevant for developing countries and examine the potential advantages of increasing broadband take-up. To analyze the significance of broadband for economic development, we specify and estimate an econometric model for nine South American countries, for which relatively high quality data was available. According to our results, increased broadband penetration is associated with significant "spillover" effects, excess societal returns over and above the expected returns of other investments in physical capital.
\end{abstract}

Keywords

broadband networks, growth externalities, penetration, productivity, digital divide

\section{Introduction}

In a global world economy, the quality of services and infrastructure is often deemed to be a key determinant of convergence for a developing country (e.g. Broadband Commission for Sustainable Development, 2018). In order to be able to reap the benefits of globalization and international trade, and facilitate rapid economic growth, these countries have to decrease their shipping, transactions and communications costs that leach away their scarce resources and might negate the (potential) competitive advantages that they could enjoy due to their lower wages. Information and Communications Technologies (ICTs) can play a key role in achieving these goals, since they can enhance firm efficiency and enable closer cooperation (or "co-opetition") with both domestic and foreign partners. Among these, broadband networks could play a special role as "General Purpose Technologies" (GPT) that enable or facilitate the use of other ICTs (OECD, 2008), including a plethora of internet-based services, such as e-commerce, e-government, e-learning or social media.

The gap that developing countries have to bridge between themselves and the rich (developed) countries seems quite daunting: in the latter, the majority of individuals and firms already have access to broadband networks (take-up is now close to saturation levels, especially in Japan, Korea and the Nordic countries), while in some poor countries, they have just recently become available. For example, in 2016 the average number of fixed broadband subscribers per 100 inhabitants ("penetration rate") was 30.3 for the UN's "developed countries" group, but only 8.7 for "developing countries", and below 1 for the "least developed countries" (ITU, 2017).

In this study, we set out the reasons why the economic effects of broadband networks should be relevant for developing countries and examine the potential advantages of increasing broadband take-up. To analyze the significance of broadband penetration for economic development, we specify and estimate an econometric model for nine South American countries, for which relatively high quality data was available. Our models not only identify broadband infrastructure as a determinant of economic growth, but also specifically measure its "spillover" effects, i.e. excess societal returns over and above the expected returns of other investments in physical capital. 
Our paper is organized as follows: In Sections 2 and 3 , we examine the concept of the "digital divide", its various interpretations and their relevance for public policies. We then provide a short literature review on the impact of broadband on economic growth in developing countries in Section 4 and introduce our modeling framework in Section 5. Finally, we present and discuss our results and some relevant policy recommendations in Sections 6 and 7.

\section{Defining and interpreting the digital divide}

The benefits of ICTs do not just accrue to for-profit firms; private consumers that are able to use these technologies efficiently can enjoy access to more and higher quality information and services, more easily and at a lower cost. The "competitive disadvantage" of the "digitally excluded" vis-à-vis these privileged individuals is known as the "digital divide" (OECD, 2001). This can arise either because these services are not available to (or unaffordable for) some individuals (lack of "materiel access") or because they lack the necessary knowledge, competence and expertise (lack of "skill access", "mental access") to utilize them (van Dijk and Hacker, 2003). Such a divide can be problematic not just because it poses a challenge to the "equality of opportunity" and since it hinders social mobility, but also because it can negatively impact on economic growth and severely restrict the role a country can play in the global value chains, especially if the majority of the population is affected.

A related but slightly different question is whether it is really important for the users to have "broadband" internet access, or whether a simple "narrowband" connection would be almost equally as useful, since it could also enable access to "texts and email"? The International Telecommunications Union's Manual still defines (fixed wired and wireless or satellite) broadband as any internet access service with advertised download speeds of at least $256 \mathrm{kbps}$, although they note that "the current $256 \mathrm{kbps}$ definition for broadband seems increasingly removed from the expectations of all stakeholders, including those in rural areas" (Broadband Commission for Sustainable Development, 2018). Some governments or regulatory authorities in developed countries, such as the Federal Communications Commission (FCC), have already adopted a more stringent definition. According to the FCC (2015), "advanced telecommunications capability" [also referred to as broadband] "requires access to actual download speeds of at least $25 \mathrm{Mbps}$ and actual upload speeds of at least 3 Mbps".
Naturally, some leisure activities like watching online videos or playing multiplayer games require faster Internet connections, but they are also necessary for some more serious applications. For instance, according to an editorial in Science (Juma and Moyer, 2008), over a decade ago, many African universities could not really benefit from a generous gesture of some publishing houses, where they made their vast archives available to them free of charge, since some of them only had a network bandwidth comparable to an average American household, and therefore their tens of thousands of students could not realistically find and download the articles (PDFs) that they were interested in. And in order to utilize the latest, most developed e-learning opportunities (upload and download HD videos of lectures, use interactive applications based on virtual or augmented reality, etc.), educational institutions would need "superfast" broadband connections that are not even widely available in developed countries (European Commission, 2016). Similarly, state-of-the-art e-health services (e.g. "High-quality, non-real-time video imaging for diagnostic purposes", "Advanced clinical decision support systems") necessitate modern ICT infrastructure (including high-speed internet access) in the hospitals but sometimes even for the patients (Jordán and de León, 2011).

According to Fuchs and Horak (2008), the "digital divide" can be investigated at both a micro and a macro level, the former as a gap between privileged and excluded individuals and firms within a society ("social divide") and the latter as a gap between the rich (developed) and poor (developing) countries ("global digital divide").

Of course, this concept can also be applied at a meso level, to analyze the difference between urban and rural regions within a country. For example, Katz (2009) remarks that even in those South American countries where broadband take-up reaches a level that could be considered adequate considering the strength of their economy, there are huge differences between the penetration rates in the capital region (agglomeration) and the rest of the country, negatively affecting the economic growth and development of the rural regions. The "digital divide" can also be interpreted at the municipal level. For instance, Iványi and Bíró-Szigeti (2019) provide an in-depth analysis of "city marketing" smartphone applications that can enhance the popularity of a city among young tourists and residents. In our study, we focus mainly on the differences at the macro level, but the micro and meso levels (the social and regional/local aspects) should also be considered relevant for broadband policy purposes. 


\section{Attitudes towards the digital divide}

According to Mariscal (2005), there are three prevalent, markedly different attitudes towards the digital divide in policy debates and the literature. The first of these, a "market economy perspective" approach states that although the benefits of ICT services and their consumption are significant, they do not warrant the provision of state aid or the adoption of special ("universal service") regulations, and their development should be left (entirely) to the market forces - competition between private firms. The proponents of this approach state that the market mechanism should be able to ensure the "socially desirable" level of quality, and any government interference would only result in an "inefficient" allocation of resources (factors of production) and harm private incentives to invest. They argue that the high correlation between economic development (GDP per capita) and the quality and quantity of ICT infrastructure (e.g. broadband take-up) is not sufficient to justify government intervention, as in their opinion, the causal relationship between the two is not bidirectional. This would mean that although richer countries have more developed ICT infrastructure and higher quality services, their availability does not result in "growth externalities" or "spillover effects" and does not contribute to faster economic growth. According to a literature survey on ICT studies published in peer-reviewed journals (Cardona et al, 2013), this view is shared by a significant minority of researchers, although it seems to be almost completely ignored by the major international organizations and most governments.

Others argue that ICTs also have significant and positive external effects, and that these effects justify their special treatment since the "societal" rates of return on some ICT investments might significantly exceed the returns expected on other investments. For example, according to the OECD (2008), ICTs have the potential to "create spillovers throughout the economy" leading to "product, process and organizational innovations"; the role of broadband networks is important mainly because they act as "the required infrastructure enabler". The proponents of this approach ("IT-for-development" (Mariscal, 2005)) opine that government intervention is often necessary to increase coverage and penetration rates in general and the situation of rural communities (isolated or sparsely populated regions) in particular.

The third group, proponents of an approach based on the concept of "social capital" (Mariscal, 2005), argue that although ICTs indeed have the potential to accelerate economic growth, their availability does not automatically guarantee that this potential can be realized, and that the government should not focus exclusively on supply-side factors (like prices, speed and coverage), as the "digital literacy" of current and potential users and institutional factors are just as important determinants of these growth externalities. Indeed, the comprehensive DESI (Digital Economy and Society Index) indicator published annually by the European Commission (2017) includes separate dimensions for "connectivity" (the availability, quality and affordability of broadband networks), and "human capital" (ICT skills and competence).

\section{Broadband and growth - a short literature review}

Due to the better quality and availability of statistical data related to ICTs, the earliest empirical studies on the economic effects of broadband had focused almost exclusively on their impact on growth, employment and productivity in developed countries (e.g. the US or the OECD countries). Most of these studies (e.g. Bojnec and Fertő, 2012; Crandall et al., 2007; Czernich et al., 2011; Koutroumpis, 2009; Thompson and Garbacz, 2008) found that these effects are indeed positive, but other researchers argued that the lack of a solid methodological framework cast doubts on some of these results (Mayo and Wallsten, 2011). (For a more comprehensive review, see Cardona et al. (2013)).

However, there is now also a growing body of literature devoted to the effects of broadband in developing countries. Perhaps one of the earliest and most well-known studies, Qiang et al.(2009) sought to quantify the relationship between economic growth and the penetration of communications networks or services (fixed and wireless telephony, internet access and broadband) between 1980 and 2009 in 120 developed and developing countries, extending Barro's (1991) cross-sectional modelling framework. They found that a higher take-up of these networks was associated with stronger economic growth, although the estimated coefficient of broadband penetration in developing countries was not statistically significant. Qiang et al. (2009) suggested that the most likely explanation for this was that broadband networks had only just begun to spread in developing countries and penetration rates were still fairly low. On the other hand, Katz (ITU, 2012) argued that the high significance and large magnitude of the dummy variables for Africa and Latin America in the article still suggested "an over-estimation of impact on GDP growth", which could have been avoided if the analysis had been conducted at lower levels of aggregation, such as states, counties or administrative departments. 
The results of Czernich et al. (2011) and Koutroumpis (2009) also suggest that broadband take-up might need to reach a "critical level" (such as $10 \%$ ) before it can exert a statistically significant effect on economic growth.

On the other hand, these findings are at odds with the results of Zaballos and López-Rivas (2012), who analyzed the economic impact of broadband with an econometric model based on panel data for Caribbean and LatinAmerican countries, and found that the positive effects of broadband are stronger at low penetration levels. According to their estimates, raising broadband take-up by 10 percentage points results in a GDP increase of $3.19 \%$, a productivity increase of $2.61 \%$ and increased employment.

A study by Ghosh (2017) examined the effects of broadband in Middle East and North African countries and also tried to identify the growth drivers that are enabled or stimulated by broadband internet access. He found that higher broadband penetration indeed has a positive economic impact, "primarily working through a reduction in broadband prices as well as greater innovation and entrepreneurial activity".

\section{Modeling framework}

Our empirical analysis is based partly on the approach of Zaballos and López-Rivas (2012), but we have also incorporated some ideas from the models of Qiang et al. (2009), which, in turn were based on a seminal paper by Barro (1991). We used a panel data set that included The World Bank (2017) data for nine South American countries (Argentina, Bolivia, Brazil, Chile, Ecuador, Colombia, Peru, Paraguay and Uruguay) for a 9-year period. Although the South American region also includes Venezuela, Guyana, Suriname and Trinidad and Tobago, these countries had to be dropped from the model due to missing data.

The basic specification (baseline model) is as follows:

$$
G_{i, t}=\alpha_{i}+\beta_{1} I_{i, t}+\beta_{2} E_{i, t}+\beta_{3} Y_{i, t}+\beta_{4} P_{i, t}+\varepsilon_{i, t} .
$$

The dependent variable, economic growth $(G)$ is calculated as a percentage change in real GDP in a given country over one year, while the regressors included the variable of interest, $P$ is the broadband penetration rate, the number of fixed broadband subscribers per 100 people and some controls. Among them, $I$ (for investment) refers to gross capital formation (as a percentage of the GDP), which also includes investments in ICT infrastructure, such as broadband networks. As a consequence, $\beta_{4}$ should capture the differential effects of broadband investments (and increased broadband take-up), which could be interpreted as "spillover" effects, excess societal returns over and above the expected returns of other investments in physical capital. $E$ stands for gross enrolment rates in primary education (as a percentage of the relevant age group) and is a proxy for human capital. Finally, $Y$ stands for the natural logarithm of the Gross Domestic Product (in USD), and its inclusion is justified by Barro's (1991:p.409) finding, that for a given quantity of human capital, economic growth is "negatively related to the initial level of per capita GDP". We also note that an econometric study by Cruz-Jesus et al. (2017) found that GDP per capita is a strong determinant of digital development (especially in developing countries), which means that $\beta_{4}$ could also capture this negative effect (thus distorting our results) if $Y$ was not included in the model.

Based on the structure of the data set (the small number of cross-sectional units that are expected to have unique institutional characteristics that are not captured by the model) and the results of the Breusch-Pagan, Hausman and F-tests, a fixed effects approach was deemed the most appropriate (although estimates based on a pooled OLS model were fairly similar). Besides the baseline model (Eq. (1)), estimates are also presented for two other variants, where the non-linear effects of broadband penetration are captured with a quadratic term, based on the suggestions of Zaballos and López-Rivas (2012); and the third model attempts to filter out the effects of the Global Economic and Financial Crisis with time dummies.

\section{Results and discussion}

The coefficient for the variable(s) of interest (in Table 1) were significant at the $1 \%$ level in all models, had the expected signs, and confirmed the observations of Zaballos and López-Rivas (2012), that the spillover effects of broadband are the strongest when the initial penetration rates are fairly low and gradually level off as take-up is increased.

Although a literal reading of the quadratic term's negative coefficients would suggest that the overall external effect of broadband could even be negative at high penetration levels, we are of the opinion that such an interpretation would lack a solid theoretical basis. On the other hand, it is not implausible that the lion's share of spillover effects result from the early take-up of broadband by large firms and main socio-economic drivers (such as educational institutions, transport hubs and other providers of public services) and that some late adopters, like retired individuals, might mainly use it for less productive activities.

The coefficients for the control variables are somewhat harder to explain, although it is worth noting that the observation period included the era of the Global Economic and Financial Crisis, which might have resulted 
Table 1 Main results (determinants of economic growth)

\begin{tabular}{|c|c|c|c|}
\hline Variable & Model 1 & Model 2 & Model 3 \\
\hline$\alpha$ (const.) & $\begin{array}{l}146.460 \\
(2.837)\end{array}$ & $\begin{array}{c}159.18 * * * \\
(3.544)\end{array}$ & $\begin{array}{c}181.294 * * * \\
(9.124)\end{array}$ \\
\hline$I$ & $\begin{array}{c}0.008 \\
(0.030)\end{array}$ & $\begin{array}{l}-0.397 * \\
(-1.986)\end{array}$ & $\begin{array}{l}-0.286^{*} \\
(-1.992)\end{array}$ \\
\hline E & $\begin{array}{c}-0.516^{* *} \\
(-2.615)\end{array}$ & $\begin{array}{c}-0.440^{* *} \\
(-2.409)\end{array}$ & $\begin{array}{c}-0.228^{* * * *} \\
(-7.033)\end{array}$ \\
\hline$Y$ & $\begin{array}{c}-10.677 * * * \\
(-2.560)\end{array}$ & $\begin{array}{c}-12.695 * * * \\
(-3.377)\end{array}$ & $\begin{array}{c}-17.495 * * * \\
(-8.624)\end{array}$ \\
\hline$P$ & $\begin{array}{c}1.579 * * * \\
(4.013)\end{array}$ & $\begin{array}{c}4.433^{* * * *} \\
(4.343)\end{array}$ & $\begin{array}{c}2.065^{* * * *} \\
(4.255)\end{array}$ \\
\hline$P^{2}$ & & $\begin{array}{c}-0.286^{* * *} \\
(-4.206)\end{array}$ & $\begin{array}{c}-0.128 * * * \\
(-2.830)\end{array}$ \\
\hline $\begin{array}{l}\text { time } \\
\text { dummies }\end{array}$ & NO & NO & YES \\
\hline$R^{2}$ & 0.351 & 0.473 & 0.780 \\
\hline adj. $R^{2}$ & 0.236 & 0.371 & 0.702 \\
\hline \multicolumn{4}{|c|}{ Fixed effects model, with robust (HAC) standard errors } \\
\hline \multicolumn{4}{|c|}{ Dependent var.: Economic growth (\% change in real GDP) } \\
\hline \multicolumn{4}{|c|}{$\begin{array}{l}\text { Cross-sectional units: Argentina, Bolivia, Brazil, Chile, Ecuador, } \\
\text { Colombia, Peru, Paraguay and Uruguay }\end{array}$} \\
\hline \multicolumn{4}{|c|}{$\begin{array}{l}\text { Legend: The first number in each cell is the value of the estimated } \\
\text { coefficients, t-statistics are in parentheses. } \\
* * * p<0.01, * * p<0.05, * p<0.1\end{array}$} \\
\hline
\end{tabular}

Source: Panel data set is based on The World Bank (2017) data

in negative returns for some investments and affected the coefficients of $I$ (which are only significant at the $10 \%$ level). The negative sign of the coefficient for $E$ is perhaps less surprising if we also note that some of the countries in the data set had gross primary enrolment rates of over $100 \%$ for most of the observation period, which might suggest that these countries are in the process of catching up and have some "overage" students. This variable is an admittedly imperfect proxy for the quality of human capital, but one that was also used by Barro (1991) and Qiang et al. (2009). Finally, the sign and significance of the coefficient for the initial GDP levels are in full accordance with our theoretical considerations.

\section{Conclusions}

In conclusion, the main results of our models seem to be supporting the views expressed by the OECD (2008), Fuchs and Horak (2008) (and other proponents of "IT-fordevelopment") and suggest that developing countries simply cannot afford to opt for a laissez-faire approach, because they would risk missing out on important growth externalities and since the lack of modern ICT infrastructure (or low take-up) could significantly worsen their chances of catching up to the "developed world" in the foreseeable future.
However, it is not so clear what could be the best strategy to increase penetration. One obvious option is to improve market conditions and promote effective competition. Based on the results of Mariscal (2005), the most important means to achieving this is safeguarding the independence and effectiveness of their regulatory authorities (market "watchdogs"), since strong competition in the market is likely to contribute to the reduction of prices, which can make ICT services affordable for more people, thus increasing penetration rates.

In addition to this, governments may also decide to launch state aid programs, following the lead of some developed countries (such as the EU, the US or Australia), by making public money available to businesses for infrastructure development projects. This solution is most likely to be adequate in less populated or poorer "rural" areas where service providers have not yet been able to build a network on a for-profit basis. However, there are also some obvious counter-arguments to large-scale state aid programs. One is that if the terms and conditions of the grant are determined with insufficient due diligence, some of these projects might distort market competition or waste public money on investments that could have been realized by private companies in the absence of state aid. A second counter-argument is that overly ambitious, costly programs might contribute to the indebtedness of developing countries.

In addition to interventions on the supply side, tackling demand-side problems could also be a relevant policy goal. Belloc et al. (2012) find that once broadband diffusion reaches an "advanced" stage, only demand-side policies appear to generate a significant positive effect. As Mariscal (2005) and van Dijk and Hacker (2003) point out, the "digital literacy" of users is an important pre-requisite to realizing the hoped-for benefits. Public institutions such as schools and universities can raise awareness to the opportunities offered by ICTs and teach citizens how these could be used for information acquisition, finding better jobs or realizing their business ideas. Overall, in our opinion, a comprehensive, well-developed strategy that takes into account all of the important micro, meso and macrolevel issues related to ICT services is needed in all developing countries.

Finally, governments in developing countries also need to realize that technology alone might not be enough to have a widespread impact on economic development. According to The World Bank (2016), "[w]hen technology is deployed in an environment of weak complements, the gains will be limited". In addition to poor infrastructure, the lack of digital skills and low digital 
adoption, many developing countries also suffer from weakly accountable institutions and are often characterized by protected markets. Improving the business climate, creating regulations that encourage competition and improving the quality and accountability of public

\section{References}

Barro, R. J. (1991) "Economic Growth in a Cross Section of Countries", The Quarterly Journal of Economics, 106(2), pp. 407-443. https://doi.org/10.2307/2937943

Belloc, F., Nicita, A., Rossi, M. A. (2012) "Whither policy design for broadband penetration? Evidence from 30 OECD countries", Telecommunications Policy, 36(5), pp. 382-398. https://doi.org/10.1016/j.telpol.2011.11.023

Bojnec, Š., Fertő, I. (2012) "Broadband availability and economic growth", Industrial Management \& Data Systems, 112(9), pp. 1292-1306. https://doi.org/10.1108/02635571211278938

Broadband Commission for Sustainable Development (2018) "The State of Broadband 2018: Broadband catalyzing sustainable development", Broadband Commission for Sustainable Development, Geneva, Switzerland. [online] Available at: https://www.itu.int/dms pub/itu-s/opb/pol/S-POL-BROADBAND.19-2018-PDF-E.pdf [Accessed: 07 June 2019]

Cardona, M., Kretschmer, T., Strobel, T. (2013) "ICT and productivity: conclusions from the empirical literature", Information Economics and Policy, 25(3), pp. 109-125.

https://doi.org/10.1016/j.infoecopol.2012.12.002

Crandall, R., Lehr, W., Litan, R. E. (2007) "The Effects of Broadband Deployment on Output and Employment: A Cross-sectional Analysis of U.S. Data", The Brookings Institution, Washington, DC, USA. [online] Available at: https://www.brookings.edu/research/ the-effects-of-broadband-deployment-on-output-and-employmenta-cross-sectional-analysis-of-u-s-data/ [Accessed: 06 July 2018]

Cruz-Jesus, F., Oliveira, T., Bacao, F., Irani, Z. (2017) "Assessing the pattern between economic and digital development of countries", Information Systems Frontiers, 19(4), pp. 835-854. https://doi.org/10.1007/s10796-016-9634-1

Czernich, N., Falck, O., Kretschmer, T., Woessmann, L. (2011) "Broadband Infrastructure and Economic Growth", The Economic Journal, 121(552), pp. 505-532. https://doi.org/10.1111/j.1468-0297.2011.02420.x

European Commission (2016) "Communication from the Commission to the European Parliament, the Council, the European Economic and Social Committee and the Committee of the Regions: Connectivity for a Competitive Digital Single Market - Towards a European Gigabit Society", European Commission, Brussels, Belgium, Rep. COM(2016) 587 final.

European Commission (2017) "Digital Scoreboard", [online] Available at: https://ec.europa.eu/digital-single-market/scoreboard [Accessed: 23 September 2017]

Federal Communications Commission (FCC) (2015) "2015 Broadband Progress Report and Notice of Inquiry on Immediate Action to Accelerate Deployment". Federal Communications Commission (FCC), Washington, DC, USA, Rep. FCC-15-10. [online] Available at: https://apps.fcc.gov/edocs_public/attachmatch/FCC-15-10A1.pdf [Accessed: 7 June 2019] institutions should be important complements to a successful digital strategy. Ideally, governments can also set an example and inspire digital adoption by using the internet to improve service delivery and increase public participation through successful e-government projects.

Fuchs, C., Horak, E. (2008) "Africa and the digital divide", Telematics and Informatics, 25(2), pp. 99-116. https://doi.org/10.1016/j.tele.2006.06.004

Ghosh, S. (2017) "Broadband penetration and economic growth: Do policies matter?", Telematics and Informatics, 34(5), pp. 676-693. https://doi.org/10.1016/j.tele.2016.12.007

International Telecommunication Union (ITU) (2012) "The Impact of Broadband on the Economy: Research to Date and Policy Issues", [pdf] International Telecommunication Union (ITU), Geneva, Switzerland, Available at: https://www.itu.int/ITU-D/ treg/broadband/ITU-BB-Reports_Impact-of-Broadband-on-theEconomy.pdf [Accessed: 07 July 2018]

ITU (2017) "World Telecommunication/ICT Indicators database 2017". (21th Edition/June 2017).

Iványi, T., Bíró-Szigeti, Sz. (2019) "Smart City: Studying Smartphone Application Functions with City Marketing Goals Based on Consumer Behavior of Generation Z in Hungary", Periodica Polytechnica Social and Management Sciences, 27(1), pp. 48-58. https://doi.org/10.3311/PPso.12451

Jordán, V., de León, O. (2011) "Broadband and the digital Revolution", In: Jordán, V., Galperin, H., Wilson, P. (eds.) Fast-tracking the digital revolution: Broadband for Latin America and the Caribbean, ECLAC, Santiago, Chile. [online] Available at: https://repositorio. cepal.org/handle/11362/35345 [Accessed 06 June 2018]

Juma, C., Moyer, E. (2008) "Broadband Internet for Africa", Science, 320(5881), Article Number: 1261. https://doi.org/10.1126/science.1161105

Katz, R. L. (2009) "Estimating broadband demand and its economic impact in Latin America", In: Proceedings of the 3rd ACORNREDECOM Conference, Mexico City, Mexico, pp. 1-20.

Koutroumpis, P. (2009) "The economic impact of broadband on growth: A simultaneous approach", Telecommunications Policy, 33(9), pp. 471-485. https://doi.org/10.1016/j.telpol.2009.07.004

Mariscal, J. (2005) "Digital divide in a developing country", Telecommunications Policy, 29(5-6), pp. 409-428. https://doi.org/10.1016/j.telpol.2005.03.004

Mayo, J. W., Wallsten, S. (2011) "From Network Externalities to Broadband Growth Externalities: A Bridge not yet Built", Review of Industrial Organization, 38(2), pp. 173-190. https://doi.org/10.1007/s11151-011-9286-8

Organisation for Economic Co-Operation and Development (OECD) (2001) "Understanding the Digital Divide", OECD Digital Economy Papers, OECD Publications, Paris, France. https://doi.org/10.1787/236405667766 
Organisation for Economic Co-Operation and Development (OECD) (2008) "Broadband and the Economy", Organisation for Economic Co-Operation and Development (OECD), Seoul, Korea, Rep. DSTI/ICCP/IE(2007)3/FINAL. [online] Available at: https://www. oecd.org/sti/40781696.pdf [Accessed: 07 June 2019]

Qiang, C. Z. W., Rossotto, C. M., Kimura, K. (2009) "Economic Impacts of Broadband", In: The World Bank (ed.) Information and Communications for Development 2009: Extending Reach and Increasing Impact, World Bank Publications, Washington, DC, USA, pp. 35-50.

https://doi.org/10.1596/978-0-8213-7605-8

Thompson, H. G., Garbacz, H. (2008) "Broadband Impacts on State GDP: Direct and Indirect Impacts", In: 17th Annual Conference of the International Telecommunications Society, Montreal, Canada, pp. 1-17. [online] Available at: http://www.imaginar.org/taller/ its2008/62.pdf [Accessed: 07 June 2018] van Dijk, J., Hacker, K. (2003) "The Digital Divide as a Complex, Dynamic Phenomenon", The Information Society: An International Journal, 19(4), pp. 315-326. https://doi.org/10.1080/01972240309487

The World Bank (2016) "World Development Report 2016: Digital Dividends", The World Bank, Washington, DC, USA. https://doi.org/10.1596/978-1-4648-0671-1

The World Bank (2017) "World Bank Open Data", [online] Available at: https://data.worldbank.org/ [Accessed: 07 June 2019]

Zaballos, A.G., López-Rivas, R. (2012) "Socioeconomic Impact of Broadband in Latin American and Caribbean Countries", InterAmerican Development Bank, Washington, DC, USA, Rep. IDB-TN-471. [online] Available at: https://publications.iadb. org/publications/english/document/Socioeconomic-Impact-ofBroadband-in-Latin-American-and-Caribbean-Countries.pdf [Accessed: 07 June 2019] 